\title{
ДМИТРИЮ МИХАЙЛОВИЧУ ГРОДЗИНСКОМУ - 85 ЛЕТ
}

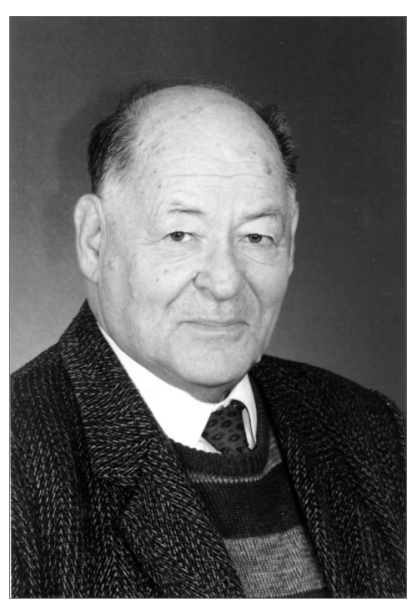

5 августа 2014 года исполняется 85 лет со дня рождения выдающегося ученого, советника Президиума Национальной академии наук Украины, дважды лауреата Государственной премии Украины, заслуженного деятеля науки и техники Украины Дмитрия Михайловича Гродзинского. Он - академик НАН Украины, дважды кавалер ордена князя Ярослава Мудрого, доктор биологических наук, профессор, заведующий отделом Института клеточной биологии и генетической инженерии НАН Украины.

Его знают как прекрасного человека с удивительно широким кругом интересов, замечательного лектора, неутомимого генератора идей с энциклопедическими знаниями в разных областях биологической науки. И эта широта интересов наполнена глубокой эрудицией, которая успевает за стремительным развитием современной науки и зачастую опережает его прогностическим видением новых идей, формированием неожиданных подходов и оригинальных концепций. Такое мировоззрение нетипично для нашего времени, когда, как правило, горизонты широкого восприятия уступают место прагматической мысли исследователя, что сужает научное познание, не позволяет глубоко видеть целостную и многогранную картину живого мира во всем его разнообразии. Радиобиологи считают его радиобиологом, физиологи растений - физиологом, экологи - экологом, эволюционисты - эволюционистом.

Откуда такая необычность юбиляра? Вероятно, это было передано от родителей, развилось еще в далеком детстве и юношестве, когда формируется круг интересов и подсознательно определяется цель в жизни, чувство ответственности перед будущим.

Д.М. Гродзинский родился в г. Белая Церковь в семье ботаников, преподавателей Белоцерковского сельскохозяйственного института. Под влиянием родителей у него с детских лет формировались привязанность к миру растений, интерес к загадкам и таинствам биологических явлений, природы. Вместе с тем он интересовался широким кругом наук от истории до физики - поэтому логичным было решение получить двойное образование. Оканчивая агрономический факультет Белоцерковского сельхозинститута, он учится на механико-математическом факультете заочного отделения Московского государственного университета им. М.В. Ломоносова. Дальше была аспирантура при Институте физиологии растений АН УССР, где Д.М. Гродзинский подготовил и защитил кандидатскую диссертацию, посвященную действию малых доз ионизирующих излучений на растения. После окончания аспирантуры он продолжал исследования в этом перспективном направлении и вско- 
ре организовал отдел биофизики и радиобиологии, которым бессменно руководит до настоящего времени.

В отделе под его руководством проводились самые разнообразные исследования, что, впрочем, не сказывалось на их глубине. Так, занимаясь изотопными исследованиями метаболизма растений, он обратил внимание на внутриклеточную компартментальность метаболических фондов и впервые изучил скорости обновления пулов аминокислот, сахаров, фосфорных соединений, липидов, некоторых ферментов фотосинтетического цикла. Результаты этих исследований были отражены в его первой монографии, посвященной использованию метода меченых атомов в физиологии и биохимии растений. Как известного специалиста, Дмитрия Михайловича пригласили в качестве эксперта ФАО ООН для работы в Югославии и оказания помощи по организации исследований в научно-исследовательских учреждениях и университетах.

Очень большое влияние на научную деятельность юбиляра оказало постоянное общение с выдающимися физиологами и биохимиками растений - академиком АН СССР А.Л. Курсановым, чл.-кор. АН СССР А.А. Ничипоровичем, П.А. Генкелем, А.Г. Лангом, Р.Г. Бутенко, Б.А. Рубиным, В.В. Полевым, Ф.Э. Реймерсом, а также с радиобиологами чл.-кор. АН СССР А.М. Кузиным, Н.В. Тимофеевым-Ресовским, Н.Ф. Батыгиным, Б.Н. Тарусовым и многими другими. Встречи с коллегами проходили в неизменно творческой атмосфере, когда формируется новое видение и зарождаются новые идеи.

С 1974 по 1985 г. Д.М. Гродзинский был директором Института физиологии растений АН УССР. Руководство институтом в этот период было делом непростым, так как замаскированный лысенкизм оказался весьма живучим и исследования ряда отделов имели повторяющийся, рутинный характер. Чтобы приблизиться к современному уровню науки, надо было решительно перестраивать методологические основы и научное мышление сотрудников. Это было сделано благодаря таланту Дмитрия Михайловича генерировать оригинальные идеи, предлагать новые формы планирования и отчетности, модернизации приборной базы, расширения информационного обеспечения исследований. Результаты сказались достаточно быстро - были сформированы новые научные направления, получены приоритетные результаты высокого уровня.

При всей широте и разносторонности научных интересов Д.М. Гродзинского в его творчестве можно выделить определенные этапы. Так, большая работа была проделана в связи с изучением роли естественной радиоактивности в жизни растений. Итогом этой работы явилась монография «Естественная радиоактивность растений и почв», в которой очерчена широкая панорама проблем, связанных с биогеохимическими процессами радиоактивных веществ земной коры. Была установлена четкая связь между способностью растений накапливать радиоактивные элементы из семейств урана-радия, актиноурана, тория и филогенетическим положением видов. Тогда же вместе со своим братом, известным академиком-физиологом Андреем Михайловичем юбиляр издал «Краткий справочник по физиологии растений», который, как и его 2-е издание, на долгие годы стал настольной книгой для всех, кто интересовался физиологией растений. Кстати, в их родном городе Белая Церковь уже появилась улица Академиков Гродзинских. К этому времени относятся и исследования им реутилизации фосфора и серы, влияния фотосинтеза на поступление минеральных веществ в растения, радиопротек- 
торного действия ионов ряда металлов. В дальнейшем Д.М. Гродзинский обратился к изучению механизмов репарации ДНК в растительных клетках, а также к раскрытию закономерностей клеточной репопуляции в меристемных тканях, подвергшихся разным типам стрессов. Уникальный характер имеют выполненные под руководством Дмитрия Михайловича исследования по трансплантации покоящегося центра корня в пораженные облучением апикальные меристемы корня.

Большое внимание Д.М. Гродзинский уделил формированию нового научного направления - теории надежности биологических систем. Он организовал и руководил научным советом АН СССР по проблемам надежности. В течение ряда лет в Чернигове в дни весенних разливов Десны проводились всесоюзные симпозиумы, посвященные различным аспектам биологической надежности - от механизмов старения до надежности экосистем. Под редакцией Д.М. Гродзинского систематически выходили сборники материалов этих симпозиумов. Надежности растительных систем была посвящена его монография, которая и сегодня является актуальной, пользуется спросом специалистов разных научных направлений.

После аварии на ЧАЭС отдел биофизики и радиобиологии переключился на исследование последствий радионуклидного загрязнения экосистем. В первые дни после катастрофы его сотрудники обследовали территории как в непосредственной близости к аварийному блоку, так и по всей Украине. Развернули исследования ранних и отдаленных эффектов хронического облучения растений. Разрабатывают новые методы оценки рисков, обусловленных радиоактивностью среды обитания, испытывают разнообразные приемы, позволяющие управлять миграцией радионуклидов в системе почва-растение, новые технологии реабилитации территорий, загрязненных радионуклидами. Вместе с тем исследуются кумулятивные эффекты облучения, воздействие хронического облучения на адаптивные процессы, а также индукция геномной нестабильности, роль диплонтного и гаплонтного клеточных отборов в защите от угрозы возрастания нагрузки на генетический аппарат в облученных популяциях растений.

Д.М. Гродзинский уделяет большое внимание проблемам, вызванным Чернобыльской катастрофой. Он одним из первых выступил против засекречивания сведений о радиационной ситуации, которая возникла в результате аварии. В то время он активно выступал на ученых советах, собраниях коллективов, в прессе, объяснял ситуацию и ее последствия, давал рекомендации по минимизации радиационных рисков. Весомость и аргументированность его действий, направленных на спасение жизни людей и принятие соответствующих решений, смогли оценить значительно позже. Более 10 лет, начиная с момента ее образования, Дмитрий Михайлович возглавлял Национальную комиссию по радиационной защите при Верховном Совете Украины, в поле зрения которой находятся все вопросы, порожденные аварией на ЧАЭС.

Д.М. Гродзинский неизменно внимателен к подготовке кадров, он создал крупную радиобиологическую научную школу. Достаточно сказать, что под его руководством подготовили и защитили кандидатские диссертации около 80 молодых специалистов не только Украины, но и других стран. 15 подготовленных им ученых стали докторами наук, из которых пять заведуют кафедрами в вузах. Д.М. Гродзинский читает различные курсы в Киевском национальном университете имени Тараса Шевченко, 
где по его инициативе создана кафедра радиобиологии и учреждена соответствующая специализация. Он написал учебник «Радиобиология», является соавтором учебников «Биофизика» и «Бионика». Всего же его перу принадлежит свыше 810 научных работ и 30 монографий.

В 1999 и 2004 гг. Дмитрия Михайловича дважды избирали на 5-летний срок академиком-секретарем Отделения общей биологии НАН УКраины. Он успешно руководит развитием биологии, обращая особое внимание на формирование новых перспективных научных направлений, проявляет неустанную заботу о решении важных для страны и дальнейшего развития науки проблем. Будучи широко эрудированным ученым, он не только уделяет большое внимание разным направлениям биологии, но старается координировать работу исследователей разных специальностей, направлять усилия на «точки роста», обеспечивая при этом комплексный подход и широкое видение проблем. Он одинаково внимательно, глубоко и компетентно рассматривает проблемы сохранения и обогащения биоразнообразия, вопросы биобезопасности, глобального потепления, развития новых биотехнологий, генной и клеточной инженерии, оригинальных подходов в классических ботанических и зоологических науках, создания и функционирования природных и биосферных заповедников.

В 2013 г. вышла книга «Адаптивная стратегия физиологических процессов растений», в основу которой положены материалы лекции, прочитанной Д.М. Гродзинским на 47-х Тимирязевских чтениях в 1986 г. Такая большая «отсрочка» выхода книги обусловлена тем, что жизнь автора со времени беспрецедентной аварии на ЧАЭС круто изменилась. Возникло множество неотложных проблем, связанных с аварией. Среди них наиболее важной оказалась проблема прогнозирования отдаленных последствий облучения по реакциям клеток и многоклеточных организмов с коротким онтогенезом. Эта проблема быстро разветвлялась, пришлось заняться изучением физиологических реакций растений в ответ на облучение, анализом изменений генетического аппарата, исследованием морфогенеза, нарушением функционирования сигнальных систем. Юбиляр сумел блестяще синтезировать первоначальное содержание лекции с новыми экспериментальными фактами и теоретическими обобщениями последних лет. Книга сразу получила высокие оценки и приобрела широкую международную известность.

Дмитрий Михайлович - организатор и руководитель Радиобиологического общества Украины, Украинской Ассоциации биологов растений, председатель Комитета научной терминологии НАН Украины, член редколлегий многих научных журналов, комиссий и комитетов. Его мнение всегда является взвешенным, аргументированным и весомым для принятия соответствующих, иногда судьбоносных решений, независимо от того, касаются они отдельного человека или научной проблемы в целом.

Много внимания Д.М. Гродзинский уделяет международным научным связям, организации совместных научных исследований. С 1971 г. он - член научного совета по проблемам радиобиологии АН СССР, a затем и научного совета РАН по радиобиологии, входил в состав бюро научного совета. Он неизменно принимает участие в организации и проведении съездов, конференций, симпозиумов. При создании под эгидой МААН Международной программы научных исследований стран СНГ «Современные проблемы радиобиологии: наука и практика» от НАН УК- 
раины в совет программы вошел Д.М. Гродзинский. В 1990-1991 гг. он был главным редактором, а в дальнейшем - членом редакционного совета научного журнала РАН «Радиационная биология. Радиоэкология».

Состояние души юбиляра в постоянном поиске новых истин, не подчинается времени и не успокаивается достигнутым. Мысли ученого устремлены к глубокому видению существа биологических процессов. Сегодня - это механизмы восприятия растениями сигналов биотической и абиотической природы, новые представления об универсальной природе позиционной информации, от которой зависит морфогенез многоклеточных организмов, создание Международной лаборатории по изучению микроэволюционных процессов, происходящих в Зоне отчуждения ЧАЭС. Не дает покоя ученому и его давняя мечта - раскрыть регуляторные механизмы систем репарации ДНК, связанные с процессами старения.

Юбиляру свойственна неувядающая энергия, доброжелательность, неизменный интерес и преданность науке. Его по праву можно назвать счастливым человеком, посвятившим жизнь любимому делу. Он обладает прекрасной памятью, знает несколько иностранных языков, большой знаток отечественной и зарубежной литературы, истории и музыки.

Ученики, друзья и коллеги искренне поздравляют Дмитрия Михайловича со славным юбилеем, желают ему крепкого здоровья, счастья, новых творческих высот и свершений. 